\title{
THE EFFECTIVENESS OF ARBUSCULAR MYCORRHIZAL FUNGI AND SALICYLIC ACID AGAINST VERTICILLIUM DAHLIAE INFECTING PEPPER (CAPSICUM ANNUUM L.)
}

\author{
COŞKUN, F. ${ }^{1}-$ DEMIR, S. ${ }^{2}-$ ALPTEKIN, Y..$^{*}$ \\ ${ }^{1}$ Department of Plant Protection, Faculty of Agriculture, Kahramanmaraş Sütçü İmam \\ University, 46100 Kahramanmaraş, Turkey \\ ${ }^{2}$ Department of Plant Protection, Faculty of Agriculture, Yüzüncü Yıl University, 65100 Van, \\ Turkey \\ ${ }^{*}$ Corresponding author \\ e-mail: alptekin69@ksu.edu.tr \\ (Received $12^{\text {th }}$ Jul 2021; accepted $1^{\text {st }}$ Oct 2021)
}

\begin{abstract}
This study was carried out to determine the effects of arbuscular mycorrhizal fungi (AMF), and salicylic acid (SA) on plant growth parameters and severity of wilt disease caused by Verticillium dahliae Kleb. in pepper. Effects of two different AMFs (Commercial AMF and Glomus intraradices) and two different SA doses $(0.5$ and $1 \mathrm{mM})$ were compared with untreated control plants after ten weeks. Both AMF species caused $62.08 \%$ and $69.07 \%$ root colonization, and the mycorrhizal dependency ratio changed from $9.08 \%$ to $59.37 \%$ in pepper plants. Commercial AMF caused a significant increase in morphological growth parameters, root colonization, mycorrhizal dependency rates and suppression of the disease severity. SA $(1 \mathrm{mM})$ resulted in improved morphological growth parameters and suppression of the severity of the disease. Besides, SA and AMF applications were found to suppress the severity of Verticillium wilt disease by $21.8 \%$ and $56 \%$ in pepper plants, respectively. Thus, the applications of SA and AMF had positive contributions to the pepper plant's morphological development.
\end{abstract}

Keywords: wilt disease, Glomus spp., plant growth regulator, disease severity, plant morphology

\section{Introduction}

Pepper (Capsicum annum L.) is an essential vegetable that accounts for $9.8 \%$ of all cultivated land and $11.1 \%$ of all vegetable production (Wang et al., 2018). Fungal diseases, however, cause $14 \%$ annual yield loss in the global vegetable production (Duran and Özkaya, 2016). Verticillium wilt, caused by the fungal pathogen Verticillium dahliae Kleb., is the most economically important of all the diseases that affect pepper plants (Vasileva and Todorova, 2020). The fungus can survive as microsclerotia in the soil and plant debris. Microsclerotia germinate and infect the roots of sensitive pepper seedlings (Caroll et al., 2018). V. dahliae colonizes the host xylem vessels, where it might block nutrient and water movements upwards (Novo et al., 2017). As a result, the pathogen causes wilting symptoms in the host plants (Carroll et al., 2018).

There have not yet, been any effective chemicals that sufficiently control the diseases (Bilgili and Güldür, 2018). Researchers have been focused on the biological management of this disease by using environmentally friendly alternatives to chemicals (Adnan et al., 2019). Enhanced nutrition, which improves host defenses, or direct restriction of pathogen development and activity, is primarily associated with biocontrol of soil-borne diseases (Rajkumar et al., 2008).

As biological control agents, arbuscular mycorrhizal fungi (AMF) infect the roots of most terrestrial plants and improve resource absorption in return for photosynthate 
(Liang et al., 2015). Different AMFs can enhance plant root tolerance or resistance at various levels under different conditions (Demir and Akköprü, 2007). Among these AMFs, Glomus intraradices is one of the best performing species causing improved plant development and prevented soil-borne pathogens (Aguilera-Gomez et al., 1999; Akköprü and Demir, 2005; Zheang et al., 2005; Şavur, 2015).

Amendment with certain abiotic factors (inducers) stimulates disease resistance by indirectly stimulating indigenous populations of microorganism beneficial to plant growth and antagonistic to plant pathogens (Rajkumar et al., 2008). Salicylic acid (SA), a primary regulator of plant growth, development, interactions with other species, and reactions to environmental stress, is among the inducers (Hayat et al., 2010).

The objectives of the present study were to find out the effects of AMF and SA on plant growth parameters of pepper plants infected with $V$. dahliae.

\section{Materials and methods}

\section{Materials}

A local pepper (Sera Demre 8) variety susceptible to Verticillium dahliae (Vd) (Coşkun et al., 2019) was used as study materials. Commercial AMF (Endo Roots Soluble - Bioglobal A.Ş.) composed of different species (Glomus intraradices, Glomus aggregatum, Glomus mosseae, Glomus clarum, Glomus monosporus, Glomus deserticola, Glomus brasillianum, Glomus etunicatum, Gigaspora margarita) and Glomus intraradices (obtained from Department of Plant Protection, Faculty of Agriculture, Yüzüncü Y1l University, Turkey) which are known to have a high relative mycorrhizal dependency were employed. In the light of the findings obtained previously on SA treatments [Salicylic acid $\left(\mathrm{C}_{7} \mathrm{H}_{6} \mathrm{O}_{3}\right) 100 \%$, İzmir Kimya, Turkey], the most appropriate $\mathrm{SA}$ doses $(0.5 \mathrm{mM}$ and $1 \mathrm{mM})$ were used, which would not cause adverse effects on plant growth. Vd, a highly virulent isolate obtained from pepper, was used in this study. The experiment was carried out in Turkey during 2019-2020.

\section{Methods}

\section{Pathogen inoculation and assessment of disease severity}

Pepper seeds were surface sterilized with $2 \%$ sodium hypochlorite. Seeds were sown in plastic viols $6 \mathrm{~cm}$ deep and $5 \mathrm{~cm}$ in diameter using a 1:1 perlite and peat growth mixture. AMF inocula $\left[2.5 \mathrm{~g}\left(25\right.\right.$ spores $\left.\left.\mathrm{g}^{-1}\right)\right]$ and SA $(0.5 \mathrm{mM}$ and $1 \mathrm{mM})$ were applied to the soil concurrently with planting.

The seedlings were placed in a growth chamber with 12 hours of fluorescent illumination at $22 \pm 2{ }^{\circ} \mathrm{C}$ and relative humidity of $60-70 \%$. Seedlings were irrigated with distilled water and fertilized three times, with $5 \mathrm{~mL}$ of diluted nutrient solution (Solution A: $\mathrm{Ca}\left(\mathrm{NO}_{3}\right)_{2}, \mathrm{KNO}_{3}$; Solution B: $\mathrm{K}_{2} \mathrm{SO}_{4}$; Solution C: $\mathrm{KH}_{2} \mathrm{PO}_{4}$; Solution D: $\mathrm{K}_{2} \mathrm{HPO}_{4}$; Solution E: $\mathrm{C}_{6} \mathrm{H}_{8} \mathrm{O}_{7}, \mathrm{C}_{4} \mathrm{H}_{6} \mathrm{O}_{5}$; Oligo-elements; Fe (Sequestrene 138), $\mathrm{MnSO}_{4}$, $\left.\mathrm{CuSO}_{4}, \mathrm{ZnSO}_{4}, \mathrm{Na}_{2}\left[\mathrm{~B}_{4} \mathrm{O}_{5}(\mathrm{OH})_{4}\right] \cdot 8 \mathrm{H}_{2} \mathrm{O}\right)$ per seedling.

$\mathrm{Vd}$ isolate was subcultured on PDA (potato dextrose agar) medium in $9 \mathrm{~mm}$ diameter petri dishes for ten days at $24^{\circ} \mathrm{C}$ in a 12-hour dark-light cycle. Seedlings were transplanted to plastic pots $(16 \times 18 \mathrm{~cm}, 2-2.5 \mathrm{lt}$ volume $)$ with equal quantities of peat and perlite after six weeks. Roots of pepper seedlings were dipped in $1 \times 10^{6}$ conidia $/ \mathrm{ml}$ Vd spor suspension and let to grow for four weeks in a growth chamber. Control plants were dipped in tap water instead of $\mathrm{Vd}$ spor suspension. 
Four weeks after pathogen inoculation, disease symptoms were examined and evaluated (Equation 1). The severity of the disease was determined based on the degree of wilted leaves using a $0-5$ scale $(0=$ Healthy; $1=$ Less than $25 \%$ wilt in leaves; $2=25 \%-50 \%$ wilt $(30 \%$ leaf loss); $3=50 \%-75 \%$ wilt $(60 \%$ leaf loss $) ; 4=75 \%-100 \%$ wilt (90\% leaf loss) (Hwang et al., 1992) and vascular health $0-3$ scale $(0=$ The plants are healthy, no discoloration in the stem cross-section; $1=$ The plants are slightly diseased, small brown stains in the stem cross-section, 1-33\% of the vascular bundles are browned; $2=$ The plants are moderately diseased, there are many black spots on the stem cross-section, 34-67\% of the vascular bundles are browned; $3=$ The plants are heavily diseased, stem cross-sections are completely covered with black spots, and the plants are dried, 68-100\% of the vascular bundles are browned) (Erwin et al., 1976). The following formula (Equation 1) was used to calculate the degree of disease severity on both scales:

$$
\text { Disease Severity }=\sum \frac{(\mathrm{n} * \mathrm{v})}{\mathrm{N} * \mathrm{~V}} * 100
$$

where $\mathrm{n}$ is the degree of disease severity on a scale, $\mathrm{v}$ is the number of plants in a category, $\mathrm{N}$ is the maximum degree of disease severity, and $\mathrm{V}$ is the total number of plants screened.

\section{AMF root colonization and mycorrhizal dependency assessment}

Plant roots were fixed and stained (Phillips and Hayman, 1970) and AMF root colonization was assessed under a stereoscope microscope (Leica/DFC295, Leica Microsystems Inc., Wetzlar, Germany) $(4 \times 10$ and $10 \times 10)$ using the grid-line intersect method according to Giovanetti and Mosse (1980). Mycorrhizal dependency assessment was determined using the method described by Declerck et al. (1995).

\section{Plant growth parameters}

A digital scale was used to determine the total fresh weight of the plants. Plants were dried at $70^{\circ} \mathrm{C}$ for 48 hours until they reached a consistent weight, and the dry weight was measured. The number of leaves, shoot length $(\mathrm{cm})$, shoot diameter $(\mathrm{cm})$, and root length $(\mathrm{cm})$ of the plants were also recorded.

\section{Statistical analysis}

The study was conducted with a randomized block design with ten replications. The data were interpreted with SPSS program (v. 22.0, IBM Corp., Armonk, NY, USA). The data were analyzed using a one-way ANOVA. Duncan's multiple comparison test was used to differentiate the treatment means.

\section{Results and discussion}

\section{Effects of two different AMF and Vd application on the plant morphology}

Effects of two different $\mathrm{AMF}$ and $\mathrm{Vd}$ alone and in combination to plant growth parameters had been shown in Table 1 and Fig. 1. Both AMFs caused a significant increase in plant growth parameters as compared to the untreated control plants. All plant growth parameters were declined in VD inoculated plants. 
Table 1. Growth parameters of pepper plants treated with AMF and Vd

\begin{tabular}{c|c|c|c|c|c|c|c|c}
\hline Treatments & $\begin{array}{c}\text { LN } \\
*\end{array}$ & $\begin{array}{c}\text { SD } \\
(\mathbf{c m})\end{array}$ & $\begin{array}{c}\text { RL } \\
(\mathbf{c m})\end{array}$ & $\begin{array}{c}\text { SL } \\
(\mathbf{c m})\end{array}$ & $\begin{array}{c}\text { RFW } \\
(\mathbf{g})\end{array}$ & $\begin{array}{c}\text { RDW } \\
(\mathbf{g})\end{array}$ & $\begin{array}{c}\text { SFW } \\
(\mathbf{g})\end{array}$ & $\begin{array}{c}\text { SDW } \\
(\mathbf{g})\end{array}$ \\
\hline \multirow{2}{*}{ Control } & 18.67 & 4.17 & 35.48 & 37.30 & 3.61 & 0.31 & 9.06 & 1.09 \\
& $\pm 1.05 \mathrm{bc}$ & $\pm 0.10 \mathrm{c}$ & $\pm 0.9 \mathrm{ab}$ & $\pm 1.14 \mathrm{~b}$ & $\pm 0.22 \mathrm{~b}$ & $\pm 0.02 \mathrm{~b}$ & $\pm 0.61 \mathrm{~b}$ & $\pm 0.08 \mathrm{~b}$ \\
& 15.83 & 3.68 & 32.06 & 33.38 & 3.04 & 0.29 & 5.66 & 0.95 \\
$\mathrm{Vd}$ & $\pm 0.67 \mathrm{c}$ & $\pm 0.10 \mathrm{~d}$ & $\pm 0.83 \mathrm{c}$ & $\pm 0.71 \mathrm{~cd}$ & $\pm 0.19 \mathrm{~b}$ & $\pm 0.01 \mathrm{~b}$ & $\pm 0.35 \mathrm{c}$ & $\pm 0.05 \mathrm{~b}$ \\
& 18.96 & 4.66 & 34.31 & 38.61 & 3.47 & 0.32 & 9.48 & 1.21 \\
$\mathrm{AMF}(\mathrm{Gi})$ & $\pm 1.07 \mathrm{bc}$ & $\pm 0.16 \mathrm{~b}$ & $\pm 0.85 \mathrm{bc}$ & $\pm 1.28 \mathrm{~b}$ & $\pm 0.26 \mathrm{~b}$ & $\pm 0.01 \mathrm{~b}$ & $\pm 0.75 \mathrm{~b}$ & $\pm 0.10 \mathrm{~b}$ \\
& 16.13 & 3.73 & 33.06 & 31.25 & 2.53 & 0.17 & 5.03 & 0.60 \\
$\mathrm{AMF}(\mathrm{Gi})+\mathrm{Vd}$ & $\pm 1.05 \mathrm{c}$ & $\pm 0.11 \mathrm{~d}$ & $\pm 1.07 \mathrm{bc}$ & $\pm 1.22 \mathrm{~d}$ & $\pm 0.27 \mathrm{c}$ & $\pm 0.01 \mathrm{c}$ & $\pm 0.43 \mathrm{c}$ & $\pm 0.07 \mathrm{~b}$ \\
& 26.20 & 5.24 & 37.73 & 42.35 & 5.11 & 0.44 & 14.25 & 1.80 \\
$\mathrm{AMF}(\mathrm{T})$ & $\pm 1.45 \mathrm{a}$ & $\pm 0.11 \mathrm{a}$ & $\pm 1.12 \mathrm{a}$ & $\pm 0.59 \mathrm{a}$ & $\pm 0.29 \mathrm{a}$ & $\pm 0.03 \mathrm{a}$ & $\pm 0.80 \mathrm{a}$ & $\pm 0.11 \mathrm{a}$ \\
& 20.06 & 4.31 & 34.13 & 35.43 & 3.68 & 0.28 & 8.22 & 1.11 \\
$\mathrm{AMF}(\mathrm{T})+\mathrm{Vd}$ & $\pm 1.44 \mathrm{~b}$ & $\pm 0.13 \mathrm{bc}$ & $\pm 0.94 \mathrm{bc}$ & $\pm 1.14 \mathrm{bc}$ & $\pm 0.35 \mathrm{~b}$ & $\pm 0.03 \mathrm{~b}$ & $\pm 0.61 \mathrm{~b}$ & $\pm 0.11 \mathrm{~b}$ \\
\hline $\mathrm{df}$ & 5 & 5 & 5 & 5 & 5 & 5 & 5 & 5 \\
$\mathrm{~F}$ & 10.64 & 22.99 & 4.10 & 14.03 & 9.93 & 11.98 & 28.45 & 18.39 \\
Sig. & 0.000 & 0.000 & 0.002 & 0.000 & 0.000 & 0.000 & 0.000 & 0.000 \\
\hline
\end{tabular}

Vd: Verticillium dahliae, AMF (T): Commercial AMF, AMF (Gi): AMF (Glomus intraradices).

* LN: leaf number; SD: shoot diameter; RL: root length; SL: Shoot length; RFW: root fresh weight; RDW: root dry weight; SFW: shoot fresh weight; SDW: shoot dry weight.

The same letters in the same column indicate the insignificant differences $(\mathrm{P}<0.05)$ according to the Duncan's test findings

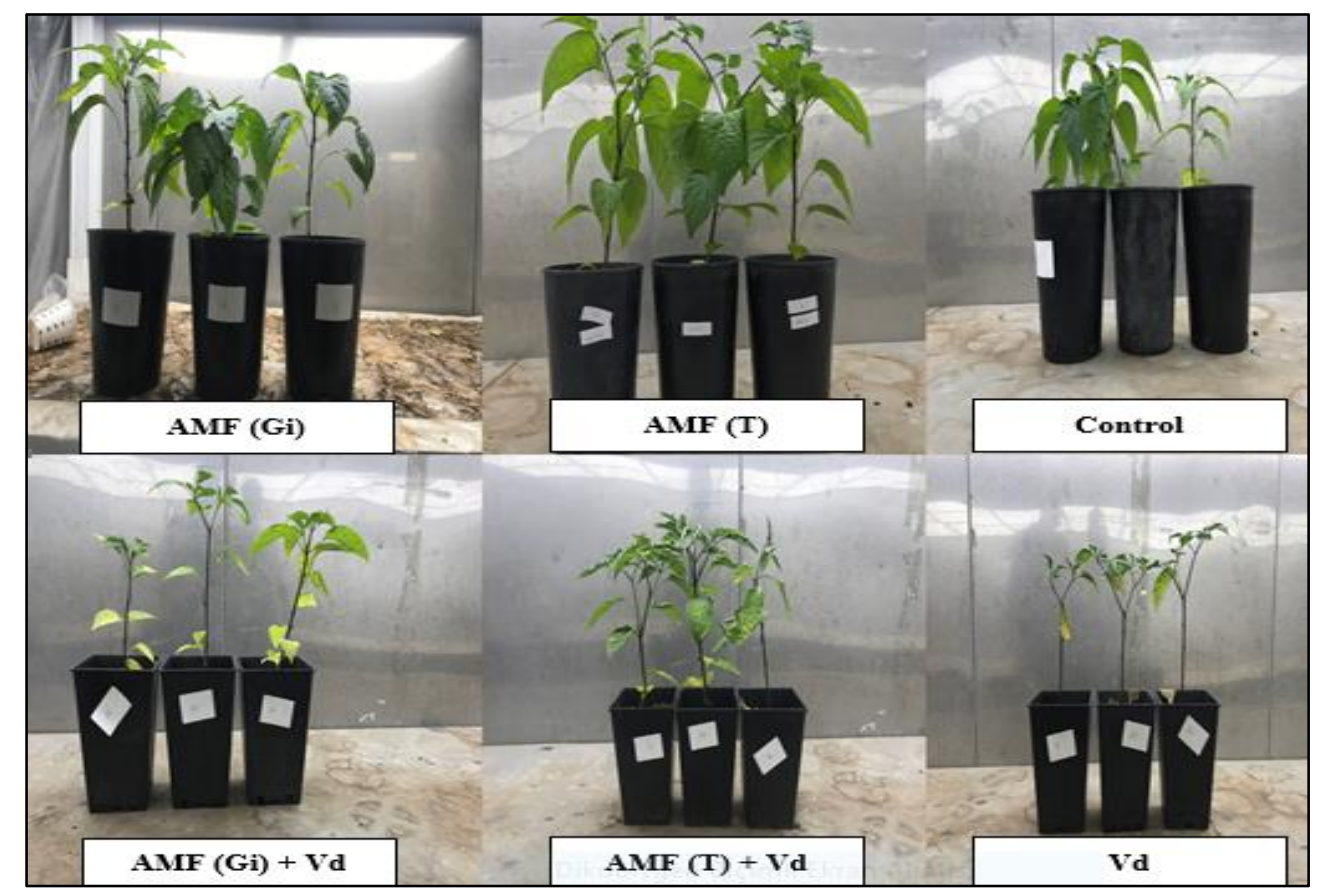

Figure 1. The appearance of pepper plants treated with different AMFs and V. dahliae

AMF inoculation improved the growth parameters in the plants inoculated with $\mathrm{Vd}$; these parameters generally remained higher than those of the control plants (Table 1, Fig. 1). AMF (T) also significantly improved the number of leaves (26.20), shoot 
diameter $(5.24 \mathrm{~cm})$, root length $(37.73 \mathrm{~cm})$, shoot length $(42.35 \mathrm{~cm})$, root fresh weight $(5.11 \mathrm{~g})$, root dry weight $(0.44 \mathrm{~g})$, shoot fresh weight $(14.25 \mathrm{~g})$ and shoot dry weight $(1.80 \mathrm{~g})$. Given the vast range of reactions from different plant cultivars to AMFs, the best cultivar-AMF pairings must be discovered to maximize the benefits of symbiosis (Sensoy et al., 2007). Although AM fungi positively encourage many cultivated plants against both biotic and abiotic stress conditions, recent studies have shown that the positive effect on plants may differ between varieties depending on genetic variation (Demir et al., 2010). It was reported that AMF promotes plant growth and increases plant tolerance to biotic stress factors such as Fusarium and Verticillium, and increases photosynthetic water use efficiency and yield. (Kaya et al., 2009; Karipçin and Şatır, 2016). Şavur (2015) reported that AMF species have positive contributions to the morphological development of the tomato plant. Bilgili and Güldür (2018) stated that three different Glomus species alone and in combination contributed to the morphological development, especially they caused a significant increase shoot fresh weight in pepper plants inoculated with Fusarium oxysporum. Güneş et al. (2019) inferred that Commercial AMF performed better than other AMF species in terms of plant development when the interactions of commercial AMF, G. intraradices, Gigaspora margarita with radish, cauliflower, spinach and nettle were examined. As a result, the effect of mycorrhizal inoculation on the growth parameters can be linked to the plant's improved nutritional condition due to AMF.

\section{Effects of different doses of salicylic acid (SA) on plant morphology}

The effects of $\mathrm{Vd}$ alone and in combination with two different doses of SA, and single doses of $0.5 \mathrm{Mm} \mathrm{SA}$ and $1 \mathrm{Mm}$ SA on plant growth parameters in pepper plants have been shown in Table 2 and Fig. 2.

Table 2. Growth parameters of pepper plants treated with SA and Vd

\begin{tabular}{|c|c|c|c|c|c|c|c|c|}
\hline Treatments & $\begin{array}{c}\mathbf{L N} \\
*\end{array}$ & $\begin{array}{c}\text { SD } \\
(\mathrm{cm})\end{array}$ & $\begin{array}{c}\mathbf{R L} \\
(\mathbf{c m})\end{array}$ & $\begin{array}{c}\text { SL } \\
(\mathrm{cm})\end{array}$ & $\begin{array}{c}\text { RFW } \\
\text { (g) }\end{array}$ & $\begin{array}{c}\text { RDW } \\
\text { (g) }\end{array}$ & $\begin{array}{c}\text { SFW } \\
(\mathrm{g})\end{array}$ & $\begin{array}{c}\text { SDW } \\
\text { (g) }\end{array}$ \\
\hline Control & $\begin{array}{l}18.67 \\
\pm 1.05 \mathrm{~b}\end{array}$ & $\begin{array}{c}4.17 \\
\pm 0.10 \mathrm{~b}\end{array}$ & $\begin{array}{c}35.48 \\
\pm 0.98 \mathrm{a}\end{array}$ & $\begin{array}{l}37.30 \\
\pm 1.14 \mathrm{a}\end{array}$ & $\begin{array}{c}3.61 \\
\pm 0.22 \mathrm{bc}\end{array}$ & $\begin{array}{c}0.31 \\
\pm 0.02 \mathrm{ab}\end{array}$ & $\begin{array}{c}9.06 \\
\pm 0.61 \mathrm{~b}\end{array}$ & $\begin{array}{c}1.09 \\
\pm 0.08 \mathrm{~b}\end{array}$ \\
\hline $\mathrm{Vd}$ & $\begin{array}{l}15.83 \\
\pm 0.67 \mathrm{~b}\end{array}$ & $\begin{array}{c}3.68 \\
\pm 0.10 \mathrm{c}\end{array}$ & $\begin{array}{l}32.06 \\
\pm 0.83 \mathrm{~b}\end{array}$ & $\begin{array}{l}33.38 \\
\pm 0.71 \mathrm{~b}\end{array}$ & $\begin{array}{c}3.04 \\
\pm 0.19 \mathrm{~cd}\end{array}$ & $\begin{array}{c}0.29 \\
\pm 0.01 \mathrm{ab}\end{array}$ & $\begin{array}{c}5.66 \\
\pm 0.35 \mathrm{~d}\end{array}$ & $\begin{array}{c}0.95 \\
\pm 0.05 \mathrm{~b}\end{array}$ \\
\hline $\mathrm{SA}(0.5 \mathrm{mM})$ & $\begin{array}{l}17.40 \\
\pm 0.92 \mathrm{~b}\end{array}$ & $\begin{array}{c}4.32 \\
\pm 0.08 \mathrm{~b}\end{array}$ & $\begin{array}{l}34.80 \\
\pm 0.85 \mathrm{a}\end{array}$ & $\begin{array}{l}33.76 \\
\pm 0.86 \mathrm{~b}\end{array}$ & $\begin{array}{c}4.53 \\
\pm 0.27 \mathrm{a}\end{array}$ & $\begin{array}{c}0.34 \\
\pm 0.02 \mathrm{a}\end{array}$ & $\begin{array}{c}8.08 \\
\pm 0.53 \mathrm{bc}\end{array}$ & $\begin{array}{c}1.08 \\
\pm 0.07 \mathrm{~b}\end{array}$ \\
\hline $\mathrm{SA}(0.5 \mathrm{mM})+\mathrm{Vd}$ & $\begin{array}{l}17.06 \\
\pm 0.70 \mathrm{~b}\end{array}$ & $\begin{array}{c}3.68 \\
\pm 0.10 \mathrm{c}\end{array}$ & $\begin{array}{l}35.53 \\
\pm 1.02 \mathrm{a}\end{array}$ & $\begin{array}{l}32.83 \\
\pm 0.87 \mathrm{~b}\end{array}$ & $\begin{array}{c}2.81 \\
\pm 0.19 \mathrm{~d}\end{array}$ & $\begin{array}{c}0.25 \\
\pm 0.01 \mathrm{~b}\end{array}$ & $\begin{array}{c}6.73 \\
\pm 0.36 \mathrm{~cd}\end{array}$ & $\begin{array}{c}1.00 \\
\pm 0.05 \mathrm{~b}\end{array}$ \\
\hline $\mathrm{SA}(1 \mathrm{mM})$ & $\begin{array}{l}28.80 \\
\pm 1.00 \mathrm{a}\end{array}$ & $\begin{array}{c}5.39 \\
\pm 0.09 \mathrm{a}\end{array}$ & $\begin{array}{l}35.01 \\
\pm 0.90 \mathrm{a}\end{array}$ & $\begin{array}{l}35.16 \\
\pm 0.65 \mathrm{ab}\end{array}$ & $\begin{array}{c}4.85 \\
\pm 0.22 \mathrm{a}\end{array}$ & $\begin{array}{c}0.35 \\
\pm 0.01 \mathrm{a}\end{array}$ & $\begin{array}{l}14.02 \\
\pm 0.45 \mathrm{a}\end{array}$ & $\begin{array}{c}1.61 \\
\pm 0.04 \mathrm{a}\end{array}$ \\
\hline $\mathrm{SA}(1 \mathrm{mM})+\mathrm{Vd}$ & $\begin{array}{l}18.47 \\
\pm 1.18 \mathrm{~b}\end{array}$ & $\begin{array}{c}4.32 \\
\pm 0.14 \mathrm{~b}\end{array}$ & $\begin{array}{l}35.59 \\
\pm 1.24 \mathrm{a}\end{array}$ & $\begin{array}{c}35.04 \\
\pm 0.99 \mathrm{ab}\end{array}$ & $\begin{array}{c}3.81 \\
\pm 0.26 \mathrm{~b}\end{array}$ & $\begin{array}{c}0.33 \\
\pm 0.02 \mathrm{a}\end{array}$ & $\begin{array}{c}7.35 \\
\pm 0.51 \mathrm{c}\end{array}$ & $\begin{array}{c}1.10 \\
\pm 0.08 \mathrm{~b}\end{array}$ \\
\hline $\mathrm{df}$ & 5 & 5 & 5 & 5 & 5 & 5 & 5 & 5 \\
\hline $\mathrm{F}$ & 28.12 & 37.90 & 2.02 & 3.48 & 12.67 & 3.25 & 38.90 & 12.75 \\
\hline Sig. & 0.000 & 0.000 & 0.049 & 0.005 & 0.000 & 0.008 & 0.000 & 0.000 \\
\hline
\end{tabular}

Vd: Verticillium dahliae, SA (0.5mM): Salicylic acid $(0.5 \mathrm{mM})$, SA (1 mM): Salicylic acid (1 mM).

* LN: leaf number; SD: shoot diameter; RL: root length; SL: shoot length; RFW: root fresh weight; RDW: root dry weight; SFW: shoot fresh weight; SDW: shoot dry weight.

The same letters in the same column indicate the insignificant differences $(\mathrm{P}<0.05)$ according to the Duncan's test findings 


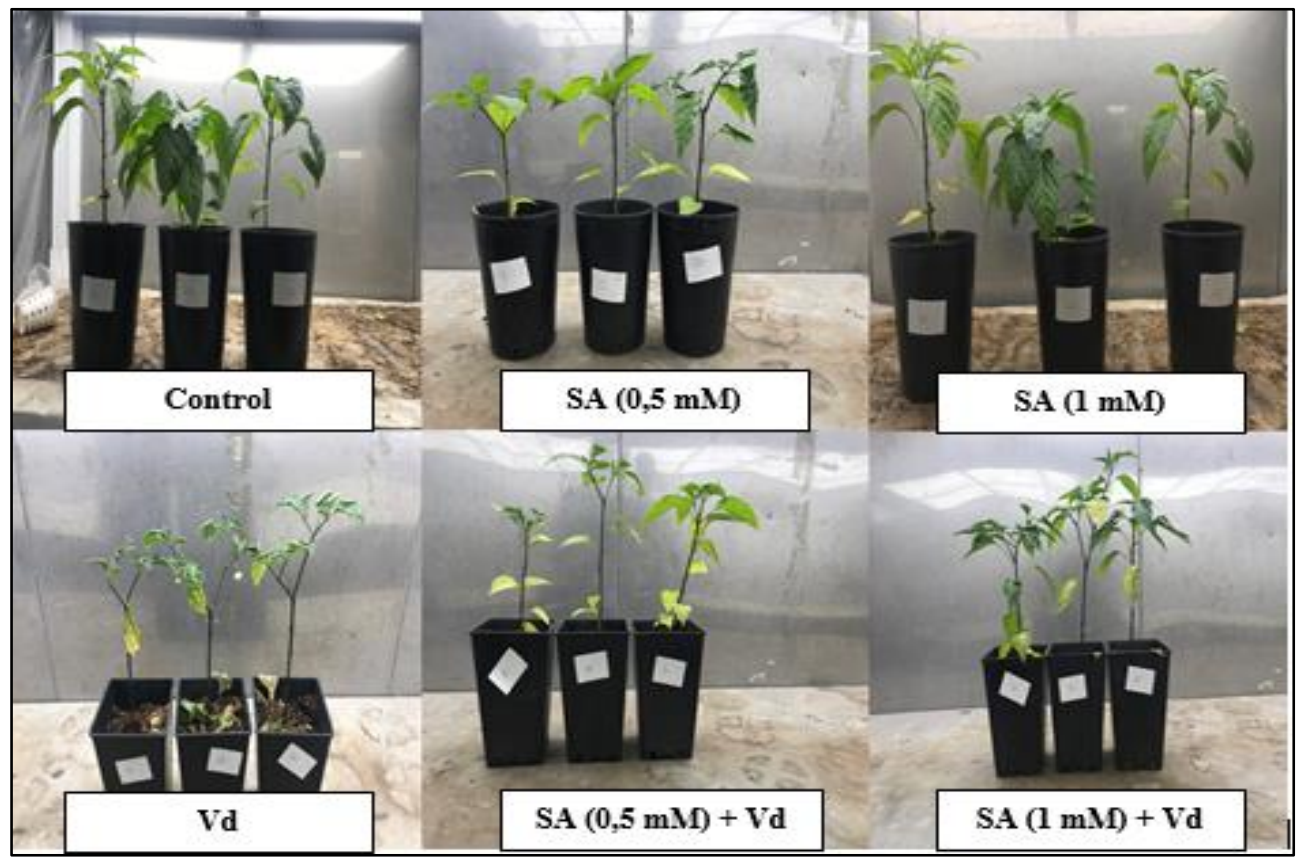

Figure 2. The appearance of pepper plants treated with different doses of SA and Vd

Vd caused a significant decline in shoot diameter, root length, shoot length, root fresh weight and shoot fresh weight, although it did not affect leaf number, root dry weight, and shoot dry weight. Vd combination with $0.5 \mathrm{Mm}$ and $1 \mathrm{mM}$ doses of SA resulted in decrease in all plant growth parameters. SA $(1 \mathrm{mM})$ treatment improved in leaf number, shoot diameter, root fresh weight, root dry weight, shoot fresh weight and shoot dry weight except for root length and shoot length. SA $(0.5 \mathrm{mM})$ treatment stimulated root fresh weight while it did not cause any increase in the other plant growth parameters (Table 2). It is shown that SA increases germination, flowering, rooting, yield and accelerates photosynthesis in plants in a number of different studies (Romanujam et al., 1998; Hayat et al., 2007; Dadaşoğlu and Ekinci, 2013; Algül et al., 2016). Elwan and ElHamahmy (2009) examined the effect of foliar application of salicylic acid (SA $10^{-6} \mathrm{M}$ and $10^{-4} \mathrm{M}$ ) on fruit yield and quality in pepper under salt stress conditions. They have reported that the application of SA $10^{-6} \mathrm{M}$ increased the average fruit weight, fruit number and fruit yield. It is also reported that SA has a positive effect on increasing the plant height of the Kandira pepper variety (Akpinar, 2011). Dura et al. (2016) investigated the effect of SA application against root-knot nematodes in 12 pepper cultivars of Yalova Chorba by applying different doses $(3 \mathrm{mM} /$ plant $-6 \mathrm{mM} /$ plant $-9 \mathrm{mM} /$ plant $)$ from leaves and soil. They determined that pepper plants with $9 \mathrm{mM} \mathrm{SA}$ application promoted plant growth parameters such as leaf number, plant height, root fresh and dry weight. Özdüven (2016) stated that SA applications increased yield, fruit number, leaf area, fruit firmness, total chlorophyll amount, protein content, single fruit weight and leaf $\mathrm{K}$ content. The study conducted by Ekbiç and Koşar (2020) studied the effects of SA doses (0, 0.5, 1 and $2 \mathrm{mM}$ ) on vine rootstocks and they concluded that the shoot growth was superior to the control and the degree of damage to the plants was lower with the application of $1 \mathrm{mM}$ dose of SA for 1103 P rootstock. The studies conducted by other researchers earlier have been supported the current study. It has been proposed that SA's growth-promoting effects 
are linked to hormonal modifications or improvements in photosynthesis, transpiration, and stomatal conductance (Rivas-San Vicente and Plasencia, 2011).

\section{Effects of AMF and SA application on the wilt disease caused by Vd in pepper}

Effects of two different AMF and two different doses of SA on the disease development in pepper are shown in Table 3.

Table 3. Effects of AMF, SA and Vd application on the wilt disease parameters (0-5 and 0-3 scale) in pepper

\begin{tabular}{|c|c|c|c|c|}
\hline \multirow[b]{2}{*}{ Treatments } & \multicolumn{2}{|c|}{$0-5$ scale } & \multicolumn{2}{|c|}{$0-3$ scale } \\
\hline & $\begin{array}{c}\text { Wilting } \\
(\%)^{*}\end{array}$ & $\begin{array}{c}\text { Suppression rate } \\
(\%)\end{array}$ & $\begin{array}{c}\text { Vascular } \\
\text { discoloration } \\
(\%)^{*}\end{array}$ & $\begin{array}{c}\text { Suppression rate } \\
(\%)\end{array}$ \\
\hline Vd (Control) & $\begin{array}{c}48.6 \\
\pm 3,67 \mathrm{a}^{*}\end{array}$ & - & $\begin{array}{c}30 \\
\pm 3,69 \mathrm{a}^{*}\end{array}$ & - \\
\hline $\operatorname{AMF}(T)+V d$ & $\begin{array}{l}22.6 \\
\pm 3,36 \mathrm{c}\end{array}$ & 53 & $\begin{array}{c}13 \\
\pm 3,42 \mathrm{~b}\end{array}$ & 56 \\
\hline $\mathrm{AMF}(\mathrm{Gi})+\mathrm{Vd}$ & $\begin{array}{c}38 \\
\pm 3,36 \mathrm{~b}\end{array}$ & 21.8 & $\begin{array}{c}16 \\
\pm 4,15 \mathrm{~b}\end{array}$ & 46.6 \\
\hline $\mathrm{SA}(0.5 \mathrm{mM})+\mathrm{Vd}$ & $\begin{array}{c}27.3 \\
\pm 3,38 \mathrm{c}\end{array}$ & 43.8 & $\begin{array}{c}16 \\
\pm 4,15 \mathrm{~b}\end{array}$ & 46.6 \\
\hline $\mathrm{SA}(1 \mathrm{mM})+\mathrm{Vd}$ & $\begin{array}{c}31.4 \\
\pm 3,79 \mathrm{bc}\end{array}$ & 35.3 & $\begin{array}{c}15 \\
\pm 3,08 \mathrm{~b}\end{array}$ & 50 \\
\hline df & 4 & - & 4 & - \\
\hline $\mathrm{F}$ & 9.16 & - & 3.27 & - \\
\hline Sig. & 0.000 & - & 0.013 & - \\
\hline
\end{tabular}

Vd: Verticillium dahliae, AMF (T): Commercial AMF, AMF (Gi): AMF (Glomus intraradices), SA $(0.5 \mathrm{mM})$ : Salicylic acid $(0.5 \mathrm{mM})$, SA (1 mM): Salicylic acid $(1 \mathrm{mM})$.

$* \mathrm{P}<0.05$ (significant)

$\mathrm{Vd}$ inoculated control plants expressed the highest disease severity values for the wilted leaf index and vascular browning (48.6\% and 30\%, respectively). AMF (T) + Vd, $\mathrm{AMF}(\mathrm{Gi})+\mathrm{Vd}, \mathrm{SA}(0.5 \mathrm{mM})+\mathrm{Vd}$ and SA $(1 \mathrm{mM})+\mathrm{Vd}$ applications resulted in the suppression of the disease development, which was $53 \%, 21.8 \%, 43.8 \%$, and $35.3 \%$ respectively; as well, the values of vascular health and suppression rate $(56 \%, 46.6 \%$, $46.6 \%$, and $50 \%$, respectively) should be noted. The best suppression of disease was observed in AMF (T) $+\mathrm{Vd}(53 \%-56 \%)$ application according to 0-5 scale and 0-3 scales (Table 3).

AMF benefits plants by increasing the uptake of phosphorus and other nutrients from the soil and increasing disease tolerance in the host plant (Merina Prem Kumari and Jeberlin Prabina, 2019). Singh et al. (2010) reported that the applications of Glomus hoi + Fusarium oxysporum, Glomus fasciculatum + Fusarium oxysporum and Rhizobium leguminosorum + Fusarium oxysporum significantly reduced the severity of the disease compared to the control applications. Aljawasim et al. (2020) found that mycorrhizal plants reduced the disease severity by $46 \%$ (Glomus clarum + Rhizoctonia solani) and $41 \%$ (Glomus mosseae + Rhizoctonia solani). Ranjbar Sistani et al. (2020) examined the yield components of AMF application against Didymella pinodes to two different varieties of sensitive and tolerant pea plants grown in pots. They concluded that AMF 
application reduced the disease severity in both varieties. In our study, AMF $(G)$ and AMF (T) applications significantly suppressed the severity of the disease caused by Vd in pepper plants. The above studies were in line with the results of the present study presented here.

Salicylic acid, as well as serving as a growth regulator, acts as a signal in the plant's defense mechanism against pests and diseases, promoting plant's resistance positively (Raskin, 1992; Arıcı and Yardımc1, 2001). Various studies have shown that SA increases the resistance to pathogens in different plants and decreases the disease severity. In this regard, Şahbaz and Akgül (2016) found that the application of SA at a dose of $50 \mathrm{~g} / 100 \mathrm{~L}$ water three times, both Fusarium oxysporum f.sp. vasinfectum and $V$. dahliae have been the most successful application in reducing disease severity in cotton plants. Tutar and Erkıliç (2016) stated that the application of 500 and 1000-ppm concentrations of SA and BABA (DL- $\beta$-aminone-butyric acid) in the eggplant plant inhibited $V$. dahliae by $27.8 \%$ and $33.3 \%$, respectively. Erkıliç et al. (2018) stated that three soil applications (SA, BABA and ASM (Acibenzolor S-Methyl)) in olive prevented the suppression of the $V$. dahliae in the vascular discoloration up to $90 \%$. ASM also was seen as the most effective application, it was determined that different concentrations of SA prevented the development of disease at a rate of $52 \%$ to $76 \%$.

\section{Effects of different AMFs and Vd application on root colonization and mycorrhizal dependency}

Effects of two different AMF and Vd application on root colonization and mycorrhizal dependency in pepper are shown in Table 4.

Table 4. Effects of different AMFs and Vd application on root colonization and mycorrhizal dependency

\begin{tabular}{|c|c|c|}
\hline Treatments & Root colonization (\%) & Mycorrhizal dependency (\%) \\
\hline $\mathrm{AMF}(\mathrm{Gi})$ & $\begin{array}{l}62.08 \\
\pm 4.84 \mathrm{ab}\end{array}$ & 9.08 \\
\hline $\mathrm{AMF}(\mathrm{Gi})+\mathrm{Vd}$ & $\begin{array}{l}54.79 \\
\pm 3.16 \mathrm{~b}\end{array}$ & - \\
\hline $\operatorname{AMF}(\mathrm{T})$ & $\begin{array}{l}69.07 \\
\pm 2.19 \mathrm{a}^{*}\end{array}$ & 59.37 \\
\hline $\operatorname{AMF}(\mathrm{T})+\mathrm{Vd}$ & $\begin{array}{l}54.95 \\
\pm 4.87 \mathrm{~b}\end{array}$ & - \\
\hline df & 3 & - \\
\hline $\mathrm{F}$ & 2.98 & - \\
\hline Sig. & 0.043 & - \\
\hline
\end{tabular}

Vd: Verticillium dahliae, AMF (T): Commercial AMF, AMF (Gi): AMF (Glomus intraradices)

$* \mathrm{P}<0.05$ (significant)

The rates of colonization in pepper plants with different AMFs and Vd application varied between $54.95 \%$ and $69.07 \%$. On the other hand, mycorrhizal dependence rates vary between AMF (Gi) 9.08\% and AMF (T) 59.37\%, but mycorrhizal dependence did not occur in applications with Vd. AMF root colonization and mycorrhizal dependency in the plant root were adversely affected by treatments that included the $\mathrm{Vd}$ pathogen (Table 4). 
AMF is under the influence of biotic and abiotic conditions; positively or negatively, it influences the colonization rates in the root zone (Akköprü and Demir, 2005). Çetinkaya and Dura (2009) determined that the fungal colonization rate was between $26 \%-30 \%$ with Endo-Roots applications in corn plant under field conditions. Y1ldiz (2010) stated that the root colonization rate of Glomus sp. was recorded as $61 \%$ in pepper, $71 \%$ in cucumber, and $72 \%$ in tomato. Aslanpay (2011) reported that AMF colonization rates of pepper varieties varied between $3.05 \%$ - 38.66\%, and mycorrhizal dependence rates varied between $2.52 \%$ and $20.64 \%$. Different pathogens can reduce AMF colonization on a variety of hosts. Aysan (2008) investigated the effects of G. mosseae, G. fasciculatum and Sclerotinia sclerotiorum applications on root colonization in bean plants. It was determined that the lowest colonization rate was in G. mosseae + Sclerotinia sclerotiorum and G. fasciculatum + Sclerotinia sclerotiorum treatments. Demir et al. (2015) stated that different AMF applications, including Vd pathogen applications, had a negative effect on root colonization. Our study showed similar results with the above studies.

\section{Conclusion}

The use of beneficial biological agents or growth regulators in the crop production should be among the important objectives in ensuring sustainable, safe and healthy production and their contribution to plant development and yield. This study aimed to determine the effects of AMF and SA on plant growth parameters and disease severity against wilt disease caused by $V$. dahliae in pepper. It was determined that SA and AMF applications generally had positive contributions to the morphological development of pepper plants and disease severity. Commercial AMF resulted in the best in morphological growth parameters, root colonization, mycorrhizal dependency rates and suppressing severity of the disease. SA $(1 \mathrm{mM})$ resulted in improved morphological growth parameters and suppression of the severity of the disease. After considering the beneficial effects of these agents on the plant's growth, their practical effect cannot be ignored. Besides, the obtained encouraging results against $V$. dahliae could help plant protection efforts. We believe that the results of our study can contribute to more detailed research in this direction.

Acknowledgements. This project was supported by the funds received from the Scientific and Technological Research Council of Turkey (TÜBİTAK Project No. 1190059).

\section{REFERENCES}

[1] Adnan, M., Islam, W., Shabbir, A., Khan, K. A., Ghramh, H. A., Huang, Z., Chen, H., Lu, G. D. (2019): Plant defense against fungal pathogens by antagonistic fungi with Trichoderma in focus. - Microbial Pathogenesis 129: 7-18.

[2] Aguilera-Gomez, L., Davies, F. J., Olalde-Portugal, V., Duray, S. A., Phavaphutanon, L. (1999): Influence of phosphorus and endomycorrhiza (Glomus intraradices) on gas exchange and plant growth of chile ancho pepper (Capsicum annuum L. cv. San Luis). Photosynthetica 36(3): 441-449.

[3] Akköprü, A., Demir, S. (2005): Biological control of Fusarium wilt in tomato caused by Fusarium oxysporum f. sp. lycopersici by AMF Glomus intraradices and some rhizobacteria. - Journal of Phytopathology 153(9): 544-550. 
[4] Akpinar, S. T. (2011): Grafted plant production and yield in grafted plants of pepper (Capsicum annuum L.) (Biberde (Capsicum annuum L.) aş1lı bitki üretme ve yetiştirme çalışmaları). - Yüksek Lisans Tezi, Namık Kemal Üniversitesi Fen Bilimleri Enstitüsü, Tekirdağ, Türkiye.

[5] Algül, B. E., Tekintaş, F. E., Günver Dalkı1lı̧, G. (2016): The usage of plant growth regulators and hormone biosynthesis booster applications (Bitki büyüme düzenleyicilerinin kullanımı ve içsel hormonların biyosentezini arttırıcı uygulamalar). - Journal of Adnan Menderes University Agricultural Faculty 13(2): 87-95.

[6] Aljawasim, B. D. G., Khaeim, H. M., Manshood, M. A. (2020): Assessment of Biocontrol Potential of Arbuscular Mycorrhizal (Glomus spp.) against Damping-Off Disease (Rhizoctonia solani) on Cucumber. - Mycorrhizal Fungi-Utilization in Agriculture and Industry Intech Open.

[7] Arıcı, Ş. E., Yardımcı, N. (2001): Induced resistance in plants (Bitkilerde uyarılmış dayanıklılık). - Atatürk Üniversitesi Ziraat Fakültesi Dergisi 32(1): 83-86.

[8] Aslanpay, B. (2011): The effects of arbuskular mycorrhizal fungus (AMF) and humic acid on the growth of pepper (Capsicum annum L.) plant and root rot disease caused by Phytophthora capsici Leonian (Arbusküler mikorhizal fungus (AMF) ve humik asitin biber (Capsicum annum L.) bitkisinin gelişimi ve Phytophthora capsici Leonian"ın neden olduğu kök boğazı çürüklüğü hastalığına etkileri). - Yüksek Lisans Tezi, Yüzüncü Yıl Üniversitesi Fen Bilimleri Enstitüsü, Van, Türkiye.

[9] Aysan, E. (2008): A research on the using of iniculation of arbuscular mycorrhizal fungus (AMF) and Rhizobium bacteria against rot root agents Sclerotinia sclerotiorum (Lib.) de Bary in the common bean (Phaseolus vulgaris L.) (Arbüsküler mikorhizal funguslar (AMF) ve rhizobium bakteri aşılamasının fasulye (Phaseolus vulgaris L.)'de kök çürüklüğü etmeni (Sclerotinia Sclerotiorum (Lib.) De Bary)'ne karşı kullanılma olanakları üzerine bir araştırma). - Yüksek Lisans Tezi, Yüzüncü Yıl Üniversitesi Fen Bilimleri Enstitüsü, Van, Türkiye.

[10] Bilgili, A., Güldür, M. E. (2018): The efficiency of arbuscular mycorrhizal fungi on Fusarium oxysporum f.sp vasinfectum root rot diseases of peppers in the GAP Region (GAP bölgesinde biberlerde Fusarium oxysporum f. sp vasinfectum kök çürüklüğü hastalığına arbüsküler mikorizal fungusların etkinliği). - Harran Tarım ve Gıda Bilimleri Dergisi 22(1): 88-108.

[11] Carroll, C. L., Carter, C. A., Goodhue, R. E., Lawell, C.-Y. C. L., Subbarao, K. V. (2018): A review of control options and externalities for Verticillium wilts. - Phytopathology 108(2): 160-171.

[12] Coşkun, F., Alptekin, Y., Demir, S. (2019): Response of some pepper (Capsicum annuum L.) varieties against wilt disease caused by Verticillium dahliae Kleb. - International Biological, Agricultural and Life Science Congress, November 7-8, 2019, Lviv, Ukraine, $164 p$.

[13] Çetinkaya, N., Dura, S. (2009): The effects of a endomycorrhizal preparate on yield and vegetative development of corn (Misır vejetatif gelişimi ve verimi üzerinde bir endomikorizal preparatın etkileri). - Ege Üniversitesi Ziraat Fakültesi Dergisi 47(1): 5359.

[14] Dadaşoğlu, E., Ekinci, M. (2013): Effects of different degrees of temperature, salt and salicylic acid applications on seed germination of bean (Phaseolus vulgaris L.) (Farkl1 sıcaklık dereceleri, tuz ve salisilik asit uygulamalarının fasulye (Phaseolus vulgaris L.) tohumlarında çimlenme üzerine etkisi). - Atatürk Üniversitesi Ziraat Fakültesi Dergisi 44(2): 145-150.

[15] Declerck, S., Plenchette, C., Strullu, D. G. (1995): Mycorrhizal dependency of banana (Musa acuminata, AAA group) cultivar. - Plant and Soil 176(1): 183-187.

[16] Demir, S., Akköprü, A. (2007): Using of Arbuscular Mycorrhizal Fungi (AMF) for Biocontrol of Soil-Borne Fungal Plant Pathogens. - In: Chincholkar, S. B., Mukerji, K. G. (eds.) Biological Control of Plant Diseases. USA: Haworth Press, pp. 124-138. 
[17] Demir, S., Orak, A. B., Demirer Durak, E. (2010): Arbuscular mycorrhizal fungus (AMF) dependency of some cotton cultivars indicating different response against Verticillium wilt (Verticillium solgunluğuna farklı reaksiyon gösteren bazı pamuk çeşitlerinin arbusküler mikorhizal funguslara (AMF) karşı mikorhizal bağımlılıkları). - Yüzüncü Y1l Üniversitesi Tarım Bilimleri Dergisi 20(3): 201-207.

[18] Demir, S., Şensoy, S., Ocak, E., Tüfenkçi, Ş., Demirer Durak, E., Erdinc, C., Ünsal, H. (2015): Effects of arbuscular mycorrhizal fungus, humic acid, and whey on wilt disease caused by Verticillium dahliae Kleb. in three solanaceous crops. - Turkish Journal of Agriculture and Forestry 39(2): 300-309.

[19] Dura, O., Sönmez, İ., Y1ldırım, K. C. (2016): Effects of salicylic acid applications on rootknot nematodes (Meloidogyne incognita) and some growth parameters in pepper (Capsicum annuиm L.) (Biberde (Capsicum annuum L.) salisilik asit uygulamalarının kökur nematodu (Meloidogyne incognita)'na ve bazı büyüme parametreleri üzerine etkileri). Bahçe 45(1): 31-39.

[20] Duran, İ., Özkaya, H. Ö. (2016): Determination of soil-borne and foliar fungal disease agents of greenhouses in Kumluca district (Kumluca ilçesi sera alanlarında toprak ve yaprak kökenli fungal hastalık etmenlerinin belirlenmesi). - Süleyman Demirel Üniversitesi Fen Bilimleri Enstitüsü Dergisi 20(1): 111-122.

[21] Ekbiç, H. B., Koşar, S. (2020): Determination of the effect of salicylic acid on improving salt resistance of grapevine rootstocks in vitro (Salisilik asidin asma anaçlarının tuza dayanımının geliştirilmesi üzerine etkisinin in vitro koşullarda belirlenmesi). - Akademik Ziraat Dergisi 9(1): 33-42.

[22] Elwan, M. W. M., El-Hamahmy, M. A. M. (2009): Improved productivity and quality associated with salicylic acid application in greenhouse pepper. - Scientia Horticulturae 122(4): 521-526.

[23] Erkılıç, A., Özdemir, S. K., Akgül, D. S. (2018): Determination of the effects of some resistance promoting chemicals against Verticillium dahliae in olive trees (Zeytinde Verticillium dahliae'ya karşı bazı dayanıklılık teşvik edici kimyasalların etkilerinin belirlenmesi). - Çukurova Tarım ve Gıda Bilimleri Dergisi 33(1): 69-76.

[24] Erwin, D. C., Tsoti, S. D., Khan, R. A. (1976): Reduction of severity of Verticillium wilt of cotton by the growth retardant tributyl (5-chloro-2-thienyl methyl) phosphonium chloride. - Phytopathology 66: 106-110.

[25] Giovannetti, M., Mosse, B. (1980): An evaluation of techniques for measuring vesicular arbuscular mycorrhizal infection in roots. - New Phytologist 84(3): 489-500.

[26] Güneş, H., Demir, S., Demirer Durak, E. (2019): Relationship between Brassicaceae, Chenopodiaceae and Urticaceae families with arbuscular mycorrhizal fungi (AMF) (Brassicaceae, Chenopodiaceae ve Urticaceae familyalarına ait bazı bitkilerin arbusküler mikorhizal funguslar (AMF)'la ilişkisi). - Kahramanmaraş Sütçü İmam Üniversitesi Tarım ve Doğa Dergisi 22: 102-108.

[27] Hayat, S., Ali, B., Ahmad, A. (2007): Salicylic Acid: Biosynthesis, Metabolism and Physiological Role in Plants. - In: Hayat, S., Ahmad, A. (eds.) Salicylic Acid: A Plant Hormone. Springer, Dordrecht, pp. 1-14.

[28] Hayat, Q., Hayat, S., Irfan, M., Ahmad, A. (2010): Effect of exogenous salicylic acid under changing environment: a review. - Environmental and Experimental Botany 68(1): 14-25.

[29] Hwang, S. F., Chang, K. F., Chakravarty, P. (1992): Effects of vesicular-arbuscular mycorrhizal fungi on the development of Verticillium and Fusarium wilts of alfalfa. - Plant Disease 76(3): 239-243.

[30] Karipçin, M. Z., Şatır, N. Y. (2016): Effect of arbuscular mycorrhizal fungi (AMF) on growth and nutrient uptake of lettuce (Lactuca sativa) under water stress (Su stresi koşullarında yetiştirilen marul sebzesinin verim ve besin içeriğine arbusküler mikorizal fungus (AMF)'un etkileri). - Yüzüncü Y1l Üniversitesi Tarım Bilimleri Dergisi 26(3): 406413. 
[31] Kaya, C., Ashraf, M., Sonmez, O., Aydemir, S., Tuna, A. L., Cullu, M. A. (2009): The influence of arbuscular mycorrhizal colonisation on key growth parameters and fruit yield of pepper plants grown at high salinity. - Scientia Horticulturae 121(1): 1-6.

[32] Liang, M., Liu, X., Etienne, R. S., Huang, F., Wang, Y., Yu, S. (2015): Arbuscular mycorrhizal fungi counteract the janzen-connell effect of soil pathogens. - Ecology 96(2): $562-574$.

[33] Merina Prem Kumari, S., Jeberlin Prabina, B. (2019): Protection of tomato, Lycopersicon esculentum from wilt pathogen, Fusarium oxysporum f. sp. lycopersici by arbuscular mycorrhizal fungi, Glomus sp. - International Journal of Current Microbiology and Applied Sciences 8(4): 1368-1378.

[34] Novo, M., Silvar, C., Merino, F., Martínez-Cortés, T., Lu, F., Ralph, J., Pomar, F. (2017): Deciphering the role of the phenylpropanoid metabolism in the tolerance of Capsicum annuum L. to Verticillium dahliae Kleb. - Plant Science 258: 12-20.

[35] Özdüven, F. F. K. (2016): Effects of salicylic acid applications on plant growth and yield of summer squash (Cucurbita pepo L.) under different irrigation levels (Salisilik asit uygulamalarının farklı sulama seviyelerinde yetiştirilen yazlık kabakta (Cucurbita pepo L.) bitki gelişimi ve verime etkileri). - Doktora Tezi, Namık Kemal Üniversitesi, Fen Bilimleri Enstitüsü, Tekirdağ, Türkiye.

[36] Phillips, J. M., Hayman, D. S. (1970): Improved procedures for clearing roots and staining parasitic and vesicular-arbuscular mycorrhizal fungi for rapid assessment of infection. Transactions of the British Mycological Society 55(1): 158-161.

[37] Rajkumar, M., Lee, K. J., Freitas, H. (2008): Effects of chitin and salicylic acid on biological control activity of Pseudomonas spp. against damping off of pepper. - South African Journal of Botany 74(2): 268-273.

[38] Ranjbar Sistani, N., Desalegn, G., Kaul, H., Wienkoop, S. (2020): Seed metabolism and pathogen resistance enhancement in Pisum sativum during colonization of arbuscular mycorrhizal fungi, an integrative metabolomics-proteomics approach. - Frontiers in Plant Science 11: 872 .

[39] Raskin, I. (1992): Role of salicylic acid in plants. - Annual Review of Plant Biology 43(1): 439-463.

[40] Rivas-San Vicente, M., Plasencia, J. (2011): Salicylic Acid beyond defense, its role in plant growth and development. - Journal of Experimental Botany 62(10): 3321-3338.

[41] Romanujam, M. P., Jaleel, V. A., Kumaravelu, G. (1998): Effect of salicylic acid on nodultion, nitrogenous compounds and related enzymes of Vigna mungo. - Biologia Plantarum 41: 307-371.

[42] Sensoy, S., Demir, S., Turkmen, O., Erdinc, C., Savur, O. B. (2007): Responses of some different pepper (Capsicum annuum L.) genotypes to inoculation with two different arbuscular mycorrhizal fungi. - Scientia Horticulturae 113(1): 92-95.

[43] Singh, P. K., Singh, M., Vyas, D. (2010): Biocontrol of Fusarium wilt of chickpea using arbuscular mycorrhizal fungi and Rhizobium leguminosorum Biovar. - Caryologia 63(4): 349-353.

[44] Şahbaz, S., Akgül, S. (2016): Fungal wilt pathogens and their management in cotton growing areas in Reyhanlı county (Hatay). - The Journal of Turkish Phytopathology 45(1): 31-43.

[45] Şavur, O. B. (2015): The effects of arbuscular mycorrhizal fungi (AMF) and salicylic acid applications against crown and rot root disease (Fusarium oxysporum f.sp. radicislycopersici Jarvis \& Shoemaker) on the some of growth and yield parameters and disease severity of tomato (Lycopersicum esculantum L.) plant (Domates kök ve kök boğazı çürüklüğü hastalığına (Fusarium oxysporum f. sp. radicis- Lycopersici Jarvis \& Shoemaker) karşı arbusküler mikorhizal fungus (AMF) ve salisilik asit uygulamalarının domates (Solanum lycopersicum L.) bitkisinin bazı gelişim ve verim parametreleri ile hastalı şiddetine etkisi). - Doktora Tezi, Yüzüncü Y1l Üniversitesi Fen Bilimleri Ensititüsü,Van, Türkiye. 
[46] Tutar, F. K., Erk1liç, A. (2016): Determination of the effects of mycorrhizal fungi and abiotic inducers against eggplant wilt diseases (Verticillium dahliae and Fusarium oxysporum f.sp. melongenae) (Patlıcanda solgunluk hastaliklari (Verticillium dahliae ve Fusarium oxysporum f. sp. melongenae)'na karş1 mikorizal fungusların ve abiyotik uyarıcıların etkilerinin belirlenmesi). - Çukurova Üniversitesi Fen ve Mühendislik Bilimleri Dergisi 34(5): 32-42.

[47] Vasileva, K., Todorova, V. (2020): Evaluation of pepper (Capsicum annuum L.) varieties to several methods of inoculation with Verticillium dahliae Kleb. in different conditions. Bulgarian Journal of Agricultural Science 26(2): 423-430.

[48] Wang, X., Zou, C., Zhang, Y., Shi, X., Liu, J., Fan, S., Liu, Y., Du, Y., Zhao, Q., Tan, Y., Wu, C., Chen, X. (2018): Environmental impacts of pepper (Capsicum annuum L) production affected by nutrient management: a case study in southwest china. - Journal of Cleaner Production 171: 934-943.

[49] Yildiz, A. (2010): A native Glomus sp. from fields in Aydın Province and effects of native and commercial mycorrhizal fungi inoculants on the growth of some vegetables. - Turkish Journal of Biology 34(4): 447-452.

[50] Zheng, H., Cui, C., Zhang, Y., Wang, D., Jing, Y., Kim, K. Y. (2005): Active changes of lignification-related enzymes in pepper response to Glomus intraradices and/or Phytophthora capsici. - Journal of Zheijang University SCIENCE B - Biomedicine \& Biotechnology 6(8): 778-786. 